\title{
Pengembangan Sistem Informasi Penerimaan Siswa Baru SMA YAPIM Medan
}

\author{
Hermanda Ihut Tua Simamora \\ Institut Agama Negeri Kristen Tarutung \\ e-mail: hermandas41@gmail.com \\ Diajukan: 7 Mei 2020; Direvisi: 10 Juli 2020; Diterima: 21 Juli 2020
}

\begin{abstract}
Abstrak
Sistem penerimaan siswa baru di sekolah menengah atas, contohnya Sekolah Menengah Atas YAPIM Medan masih dilakukan secara manual, di mana calon siswa harus datang ke sekolah untuk mengisi formulir pendaftaran. Setelah selesai mengisi formulir pendaftaran, mereka harus menyerahkan dokumen pendaftaran ke staf sekolah. Dengan sistem ini, proses penerimaan siswa belum efektif dan efisien karena melibatkan banyak pegawai dan memerlukan waktu yang panjang. Selain itu, dengan sistem penerimaan siswa yang masih manual mengakibatkan target jumlah pendaftar yang telah ditetapkan belum dapat dicapai. Untuk mengatasi kendala tersebut, maka dibuat sebuah sistem informasi penerimaan siswa baru dengan berbasis web. Sistem yang akan dibangun akan memiliki fitur pengisian formulir pendaftaran; upload berkas; verifikasi data dan berkas; serta pengumuman kelulusan. Pengembangan sistem dilakukan dengan menggunakan metode Waterfall. Bahasa pemrograman yang digunakan adalah PHP dan MySQL. Berdasarkan penelitian, penggunaan sistem informasi pendaftaran siswa baru lebih efektif dan efisien digunakan dalam sistem penerimaan siswa baru. Hal ini terjadi karena hanya melibatkan sedikit pegawai dan hanya membutuhkan waktu yang singkat. Selain itu, tidak membuang banyak dokumen fisik. Pada akhirnya, hal tersebut meningkatkan jumlah pendaftar siswa baru dari 171 pendaftar pada tahun 2018 menjadi 224 pada tahun 2019.
\end{abstract}

Kata kunci: MySQL, PHP, Sistem informasi penerimaan siswa baru, Waterfall.

\begin{abstract}
System of student admission at some Senior High School institutions, for instance Sekolah Menengah Atas Yapim Medan, has still been using manual process that students must visit the school to complete a registration form. After filling the form out, they submitted the document to school staff. However, the registration process is not effective and efficient to conduct because many peoples must be involved and consume a lot of time. Moreover, by the process, it will be difficult to reach the goal number of student's candidate. Therefore, in order to solve this issue, the school had developed an information system technology using the website. Particularly, the system was established by using waterfall methodology, whereas programming built-in PHP and MySQL. Accordingly, the features of the build system consist of registration form; document uploader; data and document verification; and announcements. Based on this research, the academic registration information system was found more effective and efficient used in the student admission. It is due to only a few people involved and merely spent a short time. Besides, it doesn't waste a number of copy-printed documents. Finally, it can increase the number of the registration rate from 171 in 2018 to 224 in 2019.
\end{abstract}

Keywords: Academic registration information system, MySQL, PHP, Waterfall.

\section{Pendahuluan}

Kualitas sumber daya manusia (SDM) merupakan komponen terpenting yang mempengaruhi kelangsungan hidup organisasi pendidikan karena kualitas SDM berpengaruh terhadap kualitas sebuah sekolah [1]. Selain faktor kualitas SDM, faktor sarana-prasarana, sistem, dan kurikulum juga mempengaruhi mutu sebuah sekolah [1]. Untuk menghasilkan kualitas sumber daya manusia, sarana dan prasarana, sistem, serta kurikulum yang baik, maka dibutuhkan dukungan sumber daya keuangan yang baik [2]. Sumber daya keuangan sekolah diperoleh dari peserta didik, sehingga jumlah peserta didik akan mempengaruhi jumlah uang yang diperoleh sekolah [3]. Jumlah peserta didik sekolah akan dipengaruhi oleh jumlah pendaftar penerimaan siswa baru, sehingga sistem penerimaan siswa baru merupakan hal 
penting bagi sekolah. Untuk dapat meningkatkan jumlah pendaftar sekolah maka dapat dilakukan dengan penerapan sistem informasi pendaftaran online [4]. Penerapan sistem informasi pendaftaran online dapat meningkatkan jumlah pendaftar siswa karena proses pendaftaran dapat dilakukan dari mana pun dan kapan pun, serta tidak dibutuhkan dokumen fisik [5]. Selain meningkatkan jumlah pendaftar, dengan penerapan sistem informasi pendaftaran online maka pendaftar tidak perlu lagi berdesak-desakan pada saat melakukan pendaftaran di sekolah [6].

SMA YAPIM Medan adalah salah satu sekolah menengah atas yang terakreditasi "A" yang ada di kota Medan. Saat ini, sistem penerimaan siswa baru masih dilakukan secara manual, di mana calon siswa harus datang ke sekolah untuk mengisi formulir pendaftaran dan menyerahkan berkas pendaftaran. Setelah pendaftaran ditutup, maka akan dilakukan seleksi calon siswa dengan penilaian berdasarkan nilai ujian nasional. Kelulusan siswa ditetapkan berdasarkan hasil pemeringkatan nilai ujian nasional dengan ketentuan bahwa jumlah siswa yang lolos tidak lebih dari kuota yang tersedia. Pengumuman nama-nama siswa yang lolos akan ditempel di papan pengumuman sekolah. Untuk melakukan pendaftaran ulang, maka siswa harus datang ke sekolah untuk mengantar berkas pendaftaran serta melakukan pembayaran uang sekolah dan pendaftaran. Dengan sistem ini, proses penerimaan siswa belum efektif dan efisien karena melibatkan banyak pegawai dan membutuhkan waktu yang panjang. Selain itu, dengan sistem penerimaan siswa yang masih manual mengakibatkan target jumlah pendaftar yang telah ditetapkan belum dapat dicapai. Untuk mengatasi kendala tersebut, maka dibuat sebuah sistem informasi penerimaan siswa baru dengan berbasis web. Sistem yang akan dibangun akan memiliki fitur pengisian form pendaftaran; upload berkas; verifikasi data dan berkas, serta pengumuman kelulusan. Dengan penerapan sistem informasi penerimaan siswa baru dapat meningkatkan efektivitas dan efisiensi proses penerimaan siswa baru, serta membantu calon siswa dalam melakukan pendaftaran [7].

Tujuan penelitian ini adalah untuk mengembangkan sistem informasi penerimaan siswa baru yang sesuai dengan kebutuhan SMA YAPIM Medan. Penggunaan sistem informasi ini diharapkan dapat meningkatkan jumlah pendaftar calon siswa baru. Peningkatan jumlah siswa baru akan meningkatkan keuangan sekolah yang akan berpengaruh terhadap peningkatan kualitas pendidikan di SMA YAPIM Medan.

Pengembangan sistem informasi penerimaan siswa baru menggunakan metode Waterfall dan alur prosesnya menggunakan Unified Modeling Language (UML). Metode Waterfall digunakan karena prosesnya sistematis dan berurutan [8], serta tidak membutuhkan waktu yang lama dalam pengembangan sistem informasi yang akan dibangun [9], sedangkan Unified Modeling Language digunakan karena dapat mempercepat proses pengembangan software, serta mengurangi biaya pengembangan [10]. Bahasa pemrograman yang digunakan untuk pengembangan sistem adalah PHP dan database-nya akan menggunakan MySQL. PHP adalah pemrograman berbasis script yang digunakan untuk mengembangkan sistem informasi berbasis web, di mana data akan diolah oleh PHP kemudian data tersebut akan ditampilkan di browser dalam bentuk HTML [11]. MySQL adalah software basisdata relasional yang mengandung sejumlah tabel data [11].

\section{Metode Penelitian}

\subsection{Teknik Pengumpulan Data}

Teknik pengumpulan data yang dilakukan dalam penelitian ini adalah:

- Pengamatan yaitu penulis melakukan pengamatan langsung ke Sekolah Menengah Atas (SMA) YAPIM Medan untuk melihat proses penerimaan siswa baru yang berlangsung.

- Wawancara yaitu penulis melakukan wawancara kepada bagian administrasi sekolah yang bertanggung jawab dalam proses penerimaan siswa baru.

- Focus group discussion yaitu berdiskusi dengan semua stakeholder yang berkaitan dengan proses penerimaan siswa baru untuk memperoleh informasi mengenai sistem yang ingin dibangun.

- Studi literatur yaitu penulis mencari sumber informasi tentang sistem informasi, sistem penerimaan siswa baru, bahasa pemrograman PHP dan database MySQL.

\subsection{Prosedur Penelitian}

Sebelum melakukan penelitian, maka peneliti merancang sebuah prosedur penelitian yang digunakan sebagai panduan dalam penelitian ini. Penelitian ini dimulai dengan menetapkan rumusan permasalahan yang dihadapi, kemudian menetapkan tujuan yang ingin dicapai. Berikutnya mencari literatur yang berkaitan dengan permasalahan penelitian, sebagai rujukan yang digunakan dalam merancang penelitian. Langkah berikutnya yaitu menetapkan metode penelitian dan pengembangan sistem. Setelah menetapkan metode, maka dilakukan pengumpulan data untuk memperoleh gambaran sistem yang 
digunakan untuk menyelesaikan permasalahan yang dihadapi. Berdasarkan data yang diperoleh, maka dirancang alur program sesuai dengan apa yang telah ditetapkan oleh peneliti dan pihak sekolah. Agar mudah dipahami maka alur program dibangun menggunakan Pemodelan UML. Program dibuat berdasarkan hasil desain alur program yang telah ditetapkan. Uji program dilakukan untuk memastikan tidak ada error program dan memastikan program yang dibuat telah sesuai dengan kebutuhan sekolah. Untuk detail mengenai langkah-langkah prosedur penelitian yang dilakukan dalam penelitian ini dapat dilihat pada Gambar 1.

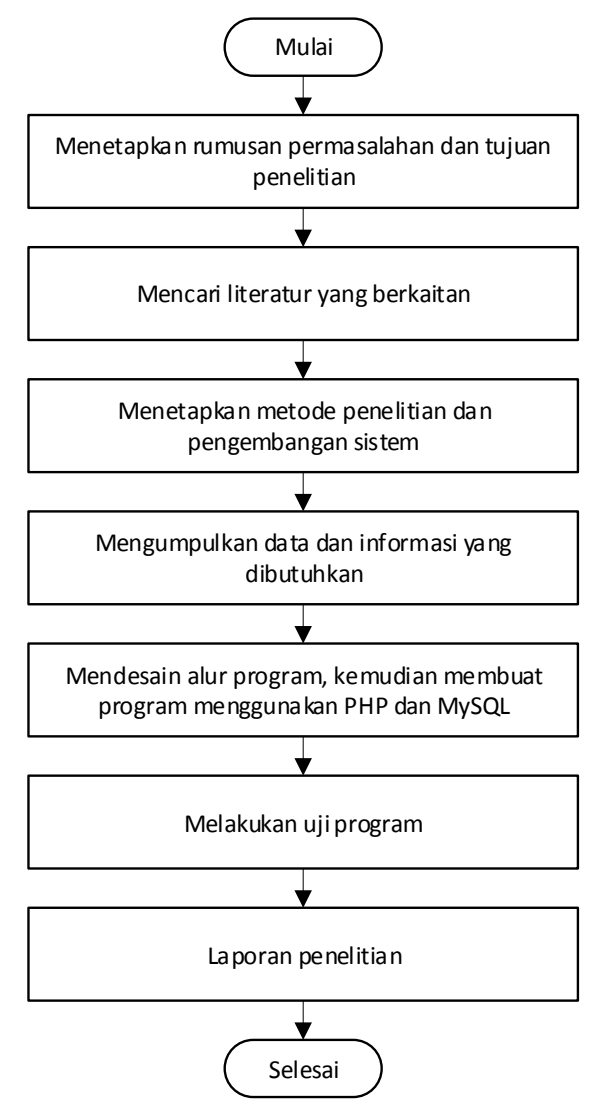

Gambar 1. Prosedur penelitian.

\subsection{Metode Pengembangan Sistem}

Metode Waterfall adalah metode yang dipilih untuk pengembangan sistem dalam penelitian ini karena metode ini tepat digunakan untuk pengembangan sistem yang tidak terlalu besar dan sumber daya yang terlibat dalam jumlah sedikit [9]. Langkah-langkah pengerjaan sistem dengan metode Waterfall dapat dilihat pada Gambar 2 [12].

I. Requirements Analysis and Definition

Melakukan analisis terhadap kebutuhan sistem yang akan dibangun, dengan mewawancarai pihak sekolah serta mengamati proses yang sedang berlangsung. Peneliti dan pihak sekolah akan menetapkan kebutuhan sistem yang akan digunakan dalam melakukan desain alur program.

II. System and Sofftware Design

Peneliti akan membuat alur program dan algoritma yang akan digunakan secara detail berdasarkan hasil analisis kebutuhan. Dalam pemodelan alur program, peneliti akan menggunakan Unified Modelling Language (UML).

III. Implementation and Unit Testing

Mengembangkan sistem ke dalam sebuah program dengan menggunakan bahasa pemrograman PHP dan database MySQL. Setelah program selesai dibuat, maka akan dilakukan unit testing untuk memastikan tidak ada lagi error pada setiap modul sistem.

IV. Integration and System Testing

Melakukan penggabungan terhadap modul-modul yang telah dibuat, kemudian melakukan pengujian sistem secara keseluruhan untuk mengetahui apakah sudah sesuai dengan kebutuhan dan alur program. 
V. Operation and Maintenance

Setelah melewati tahapan pengujian, maka sistem akan dijalankan sebagai operasional dalam melakukan penerimaan mahasiswa baru. Maintenance akan dilakukan apabila ada masalah atau dibutuhkan perubahan terhadap sistem.

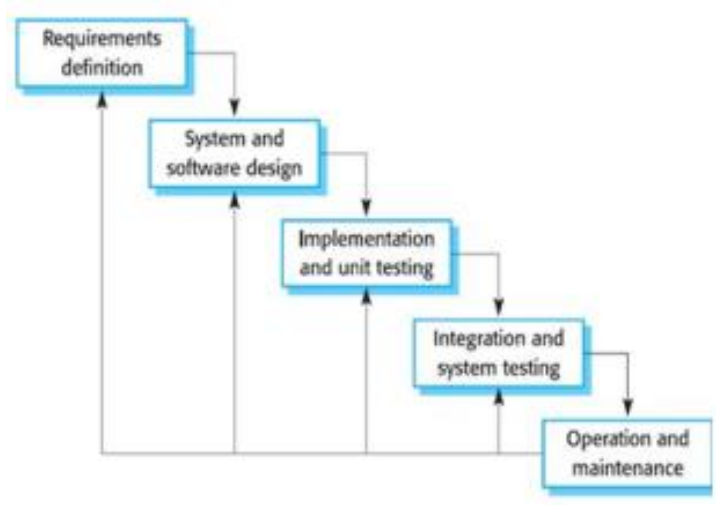

Gambar 2. Metode Waterfall.

\section{Hasil dan Pembahasan}

Desain sistem dibuat berdasarkan hasil analisis terhadap kebutuhan yang dilakukan oleh peneliti dan pihak sekolah. Setelah di desain, tahap selanjutnya yaitu melakukan implementasi ke dalam sebuah program menggunakan PHP dan MySQL. Program yang telah dibuat diuji untuk memastikan program yang dibuat terbebas dari error dan telah sesuai dengan kebutuhan sekolah.

\subsection{Analisis kebutuhan sistem}

Tahap ini dilakukan untuk mengetahui kebutuhan sistem dan kebutuhan fungsional dari sistem yang dibangun. Berikut adalah hasil analisis yang dilakukan:

\subsubsection{Kebutuhan sistem}

Berikut adalah kebutuhan minimal yang harus dipenuhi untuk menjalankan sistem:

- Perangkat keras (hardware)

a) 1 Giga Hertz (GHz) atau prosesor dengan kecepatan 32-bit (x86) atau 64-bit (x64)

b) RAM 1 GB untuk 32-bit atau 2 GB untuk 64-bit

c) Media penyimpanan yang tersedia 16 GB (32-bit) atau 20 GB (64-bit)

d) Kartu grafis DirectX 9 dengan driver WDDM 1.0 atau lebih tinggi

e) Monitor dan Keyboard

- Perangkat lunak (software)

a) Apache sebagai web server.

b) MySQL sebagai database server

c) Sistem Operasi Windows 7/10

\subsubsection{Kebutuhan fungsional}

Dalam sistem ini terdapat 2 aktor yang berkaitan dengan sistem yaitu administrator dan calon siswa, sehingga kebutuhan fungsional yang harus dipenuhi adalah fungsional untuk administrator dan calon siswa. Kebutuhan fungsional dari administrator yaitu melakukan login, input atau edit artikel, verifikasi data calon siswa, ubah atau hapus pengguna, membuat pengumuman kelulusan, dan penentuan kelulusan siswa. Sedangkan kebutuhan fungsional calon siswa melakukan registrasi, login, input biodata, upload biodata pendukung, view pengumuman, dan daftar ulang.

\subsection{Perancangan Sistem}

\subsubsection{Use Case Diagram}

Terdapat dua aktor yang berkaitan langsung dengan sistem, yaitu administrator dan calon siswa. Untuk dapat memahami proses yang terjadi antar aktor dengan sistem, maka berikut digambarkan dalam bentuk use case diagram. 


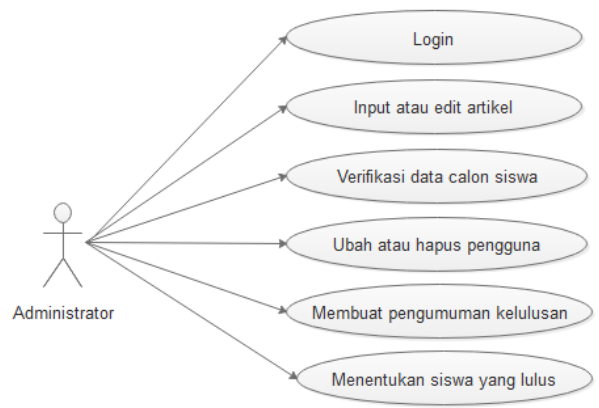

Gambar 3. Use case diagram administrator.

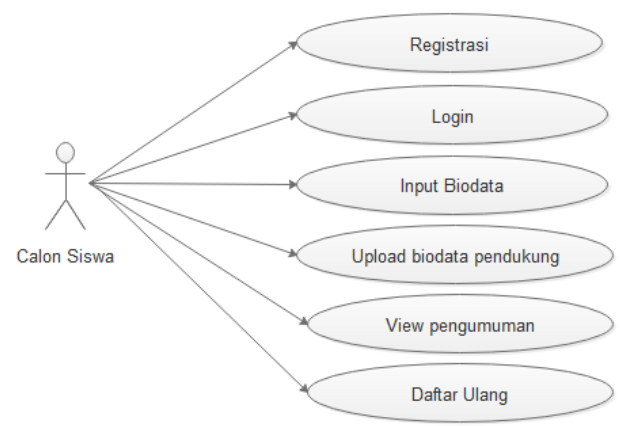

Gambar 4. Use case diagram calon siswa.

\subsubsection{Entity Relationship Diagram}

Entity relationship diagram digunakan untuk menggambarkan hubungan antar entitas yang ada di dalam sistem. Entity Relationship Diagram (ERD) dibuat berdasarkan hasil analisis kebutuhan sistem yang telah dilakukan. Berdasarkan hasil analisis kebutuhan maka sistem yang dibangun terdiri dari 9 tabel yaitu tabel artikel, pengumuman, profile, siswa daftar ulang, siswa gagal, siswa lulus, user, verifikasi gagal, dan verifikasi lulus.

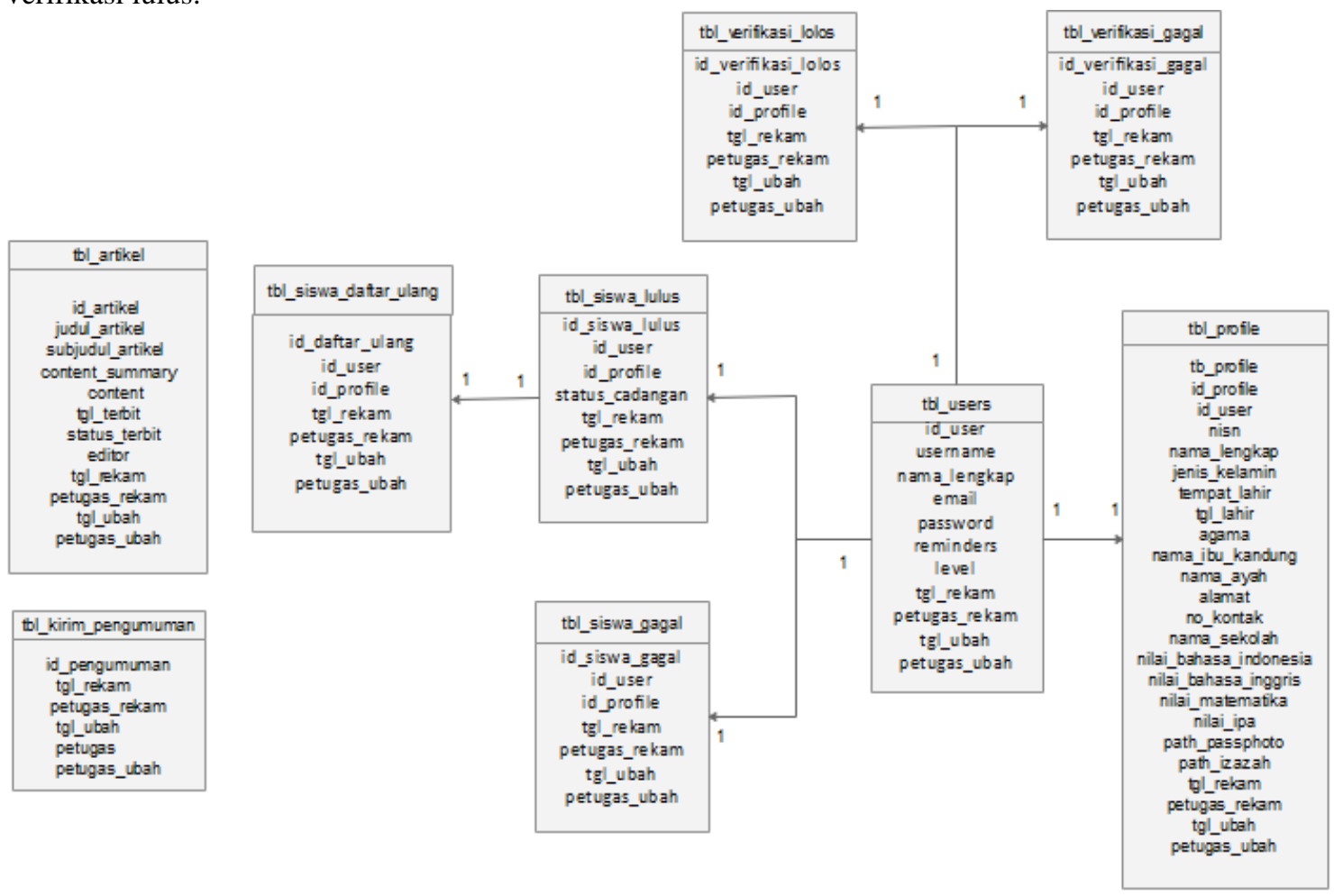

Gambar 5. Entity Relationship Diagram. 


\subsection{Implementasi}

Pertama kali akses ke website maka otomatis akan diarahkan ke halaman Home. Berikut adalah halaman Home:

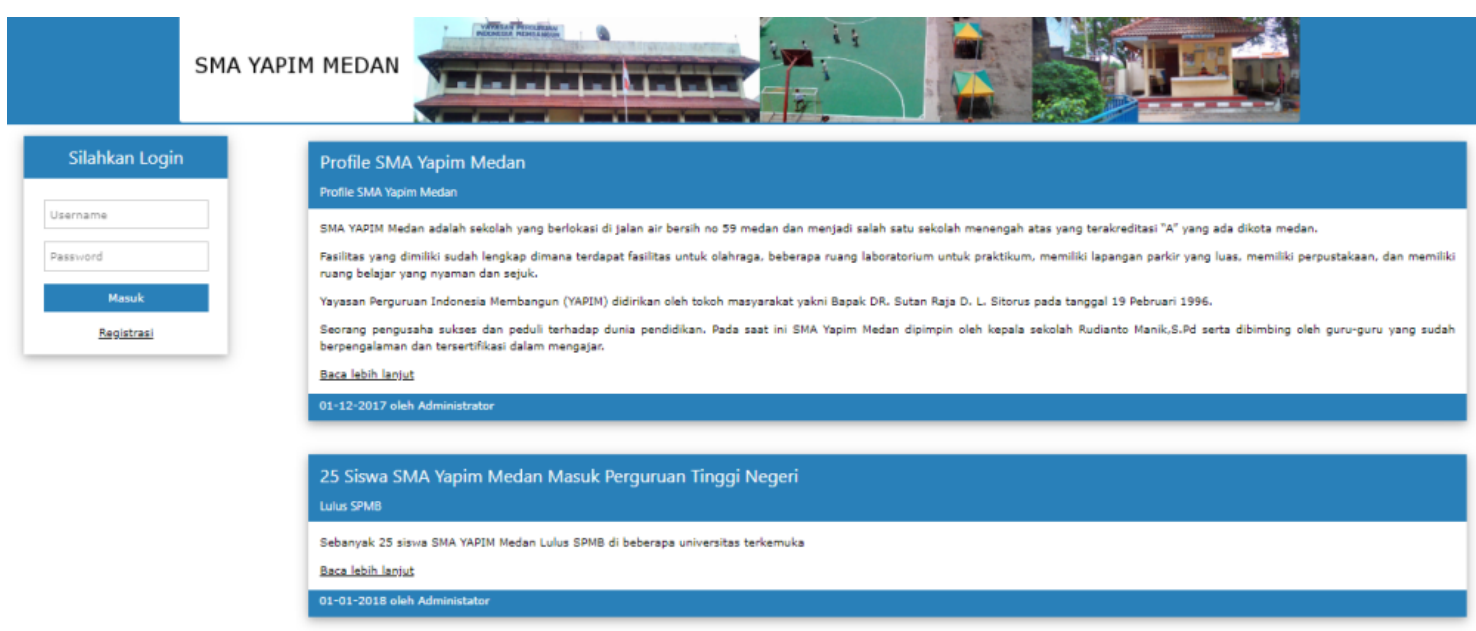

Gambar 6. Halaman Home.

Untuk melakukan pendaftaran maka calon siswa harus mengeklik register, kemudian calon siswa akan diarahkan ke halaman register. Calon siswa harus mengisi informasi yang diminta di form register.

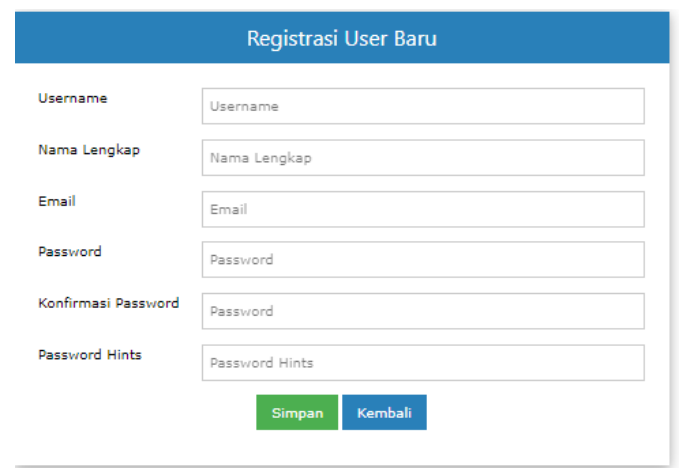

Gambar 7. Halaman register.

Setelah melakukan pendaftaran maka calon siswa harus login menggunakan username dan password yang telah didaftarkan.

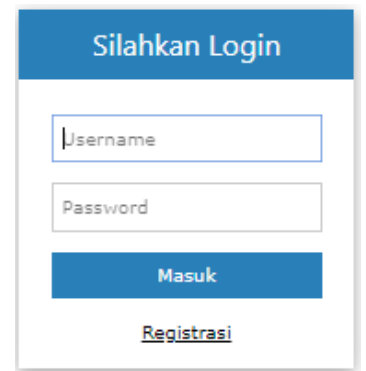

Gambar 8. Halaman login.

Setelah login, calon siswa harus mengisi informasi sesuai dengan form biodata calon siswa dan nilai siswa. 


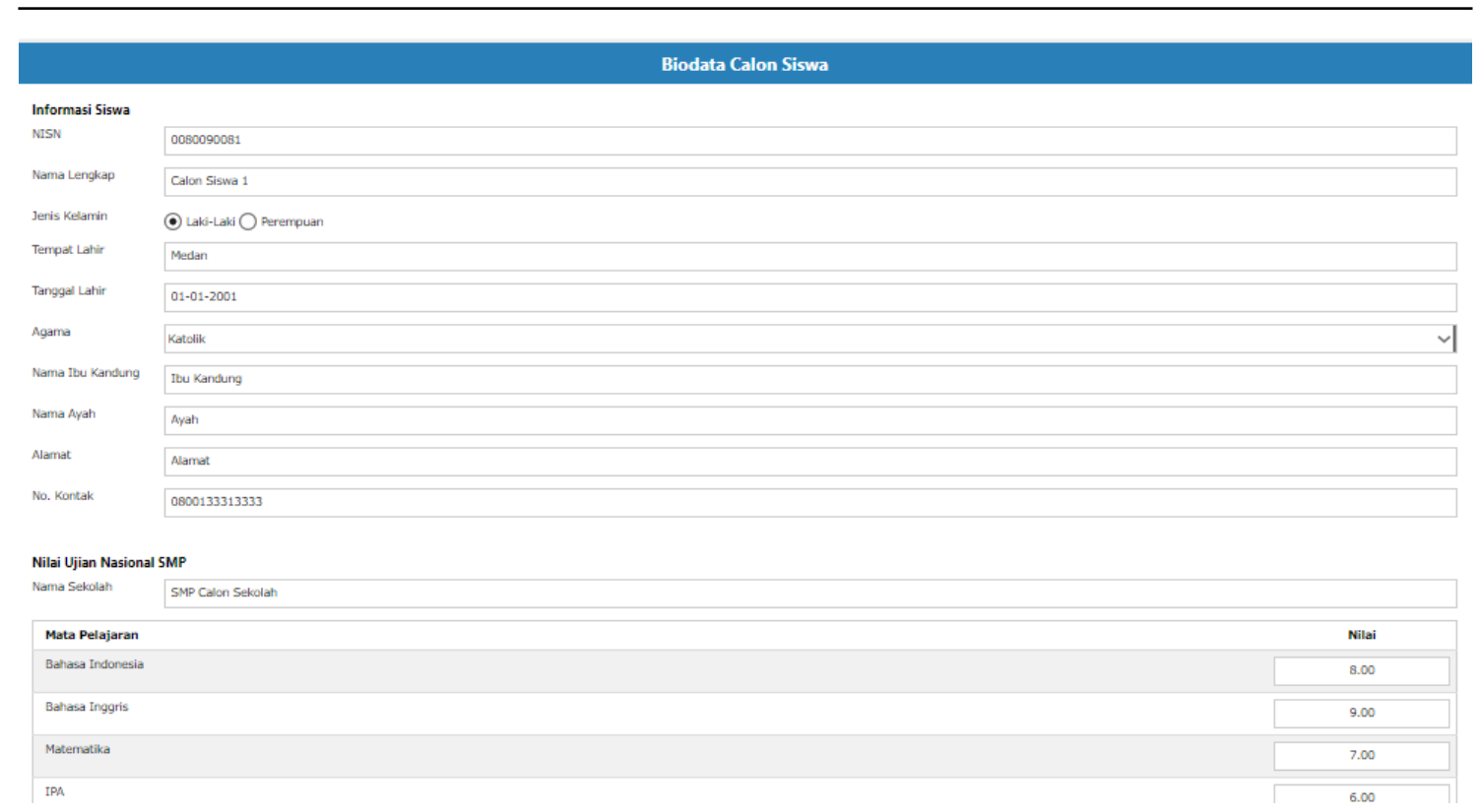

Gambar 9. Halaman informasi siswa. ijazah.

Setelah mengisi biodata dan nilai, calon siswa harus mengunggah berkas pendukung pasfoto dan

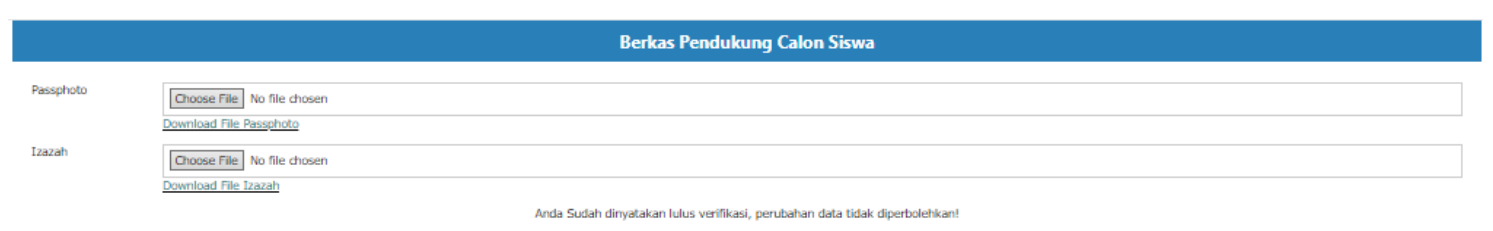

Gambar 10. Halaman berkas pendukung.

Untuk melihat hasil kelulusan, maka calon siswa dapat mengakses halaman pengumuman.

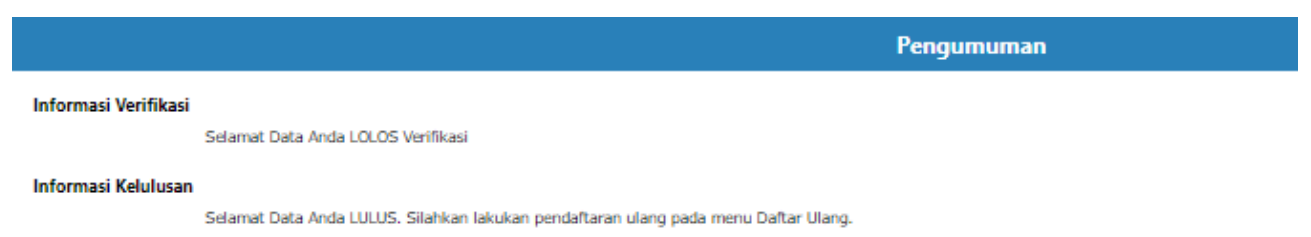

Gambar 11. Halaman pengumuman.

Apabila calon siswa dinyatakan lulus, maka calon harus melakukan daftar ulang dengan mengakses halaman daftar ulang.

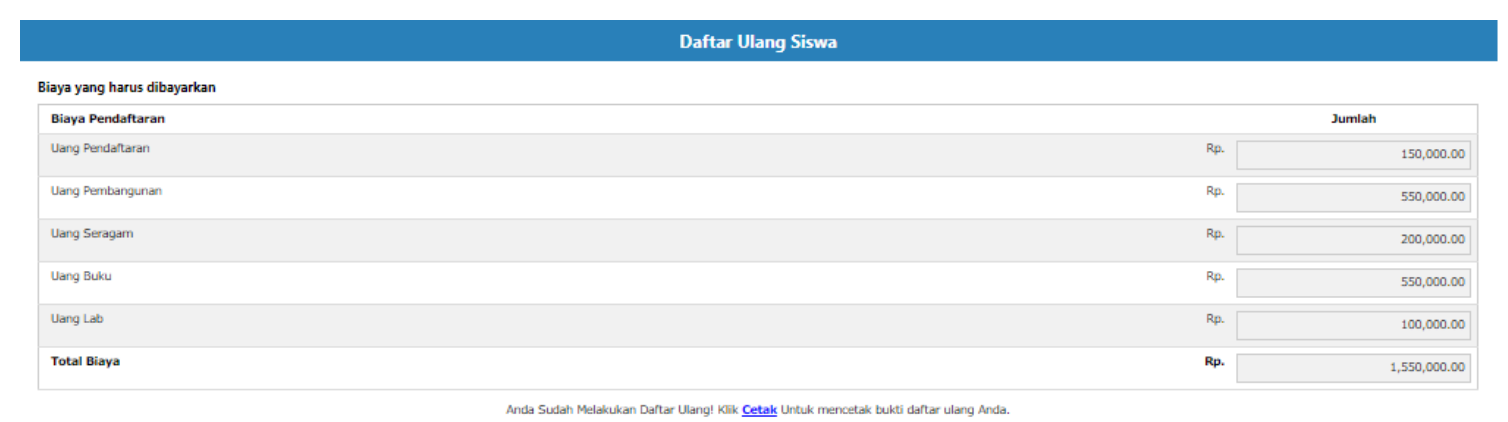

Gambar 12. Halaman daftar ulang. 
Apabila siswa telah melakukan daftar ulang maka, siswa dapat mencetak bukti daftar ulang.

Form Daftar Ulang

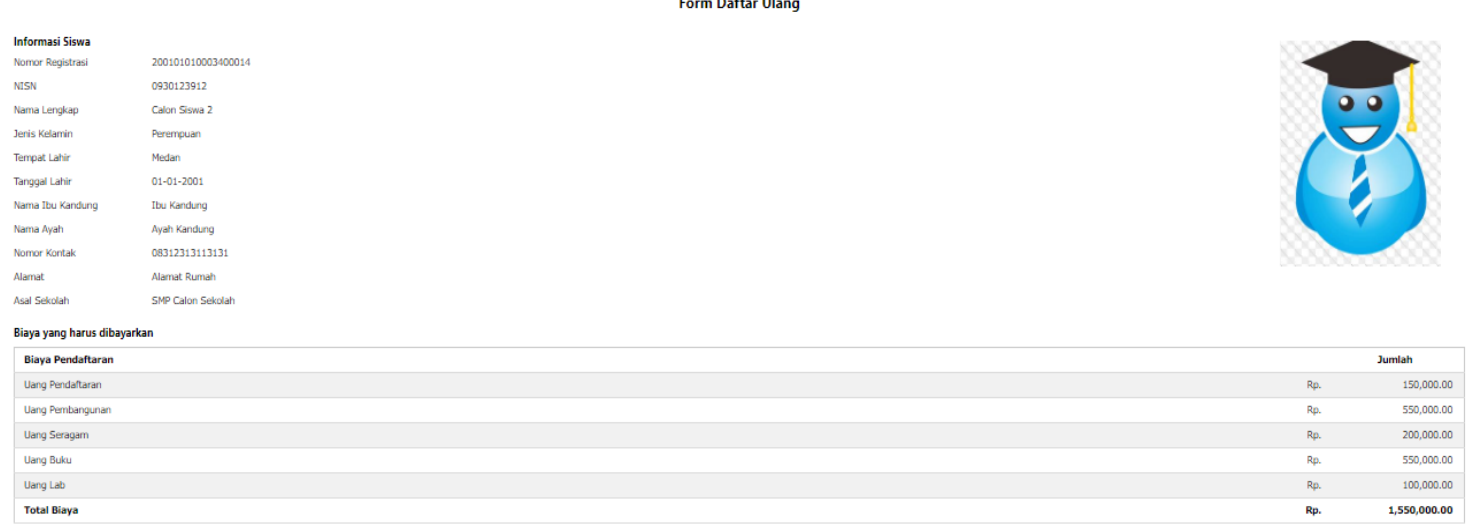

Gambar 13. Bukti daftar ulang.

Untuk dapat mengakses halaman administrator, maka admin harus input username dan password administrator di halaman login.

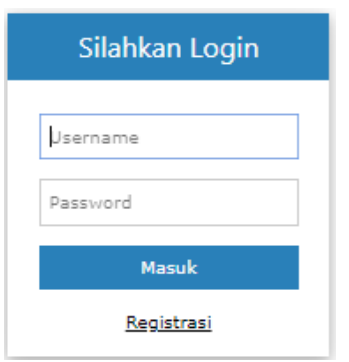

Gambar 14. Halaman login.

Untuk membuat artikel maka admin dapat mengakses halaman penambahan artikel

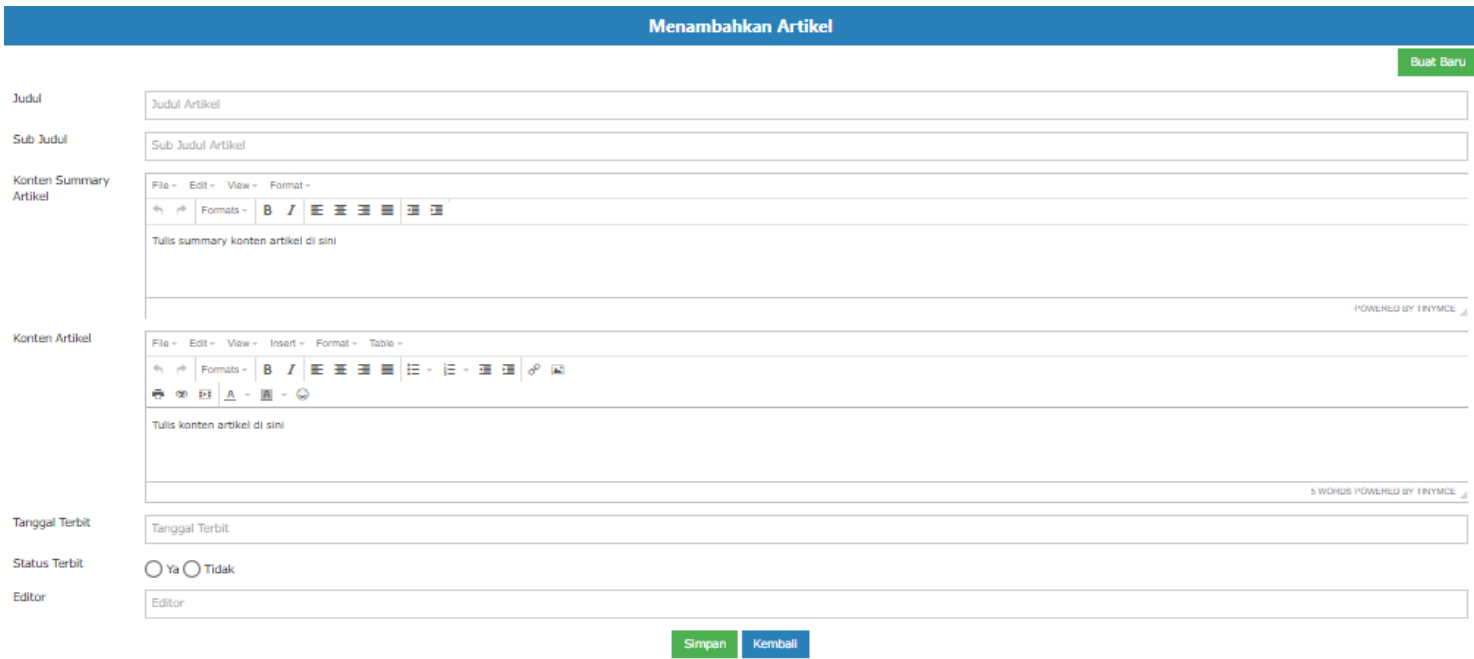

Gambar 15. Halaman artikel.

Untuk dapat melakukan verifikasi data dan nilai siswa, maka admin harus mengakses halaman data siswa. 


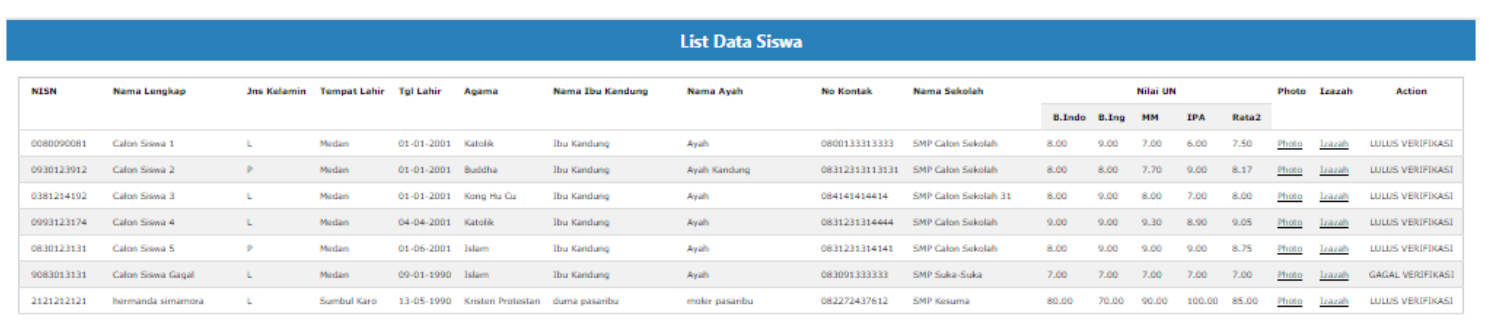

Gambar 16. Halaman data siswa.

Untuk melihat dan membatalkan data siswa yang lulus verifikasi, maka admin harus mengakses halaman siswa lulus verifikasi.

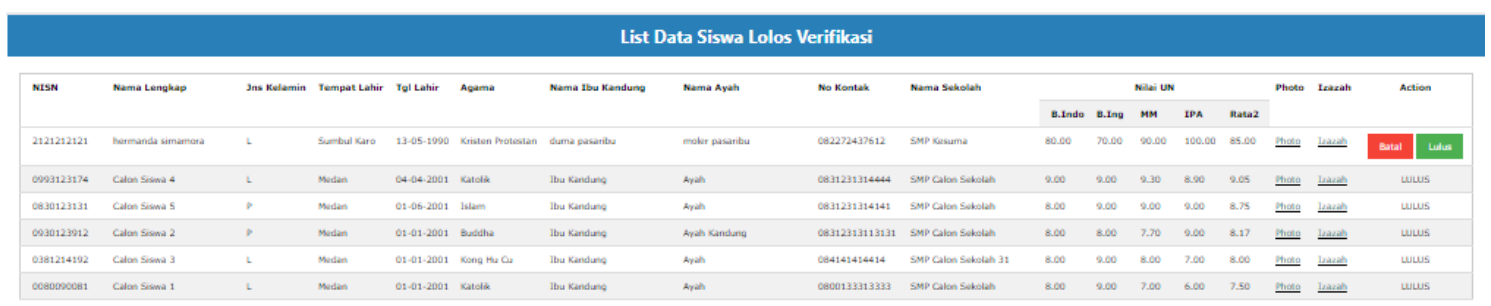

Gambar 17. Halaman data siswa lulus verifikasi.

Untuk melihat dan membatalkan siswa yang gagal verifikasi, maka admin harus mengakses halaman siswa gagal verifikasi.

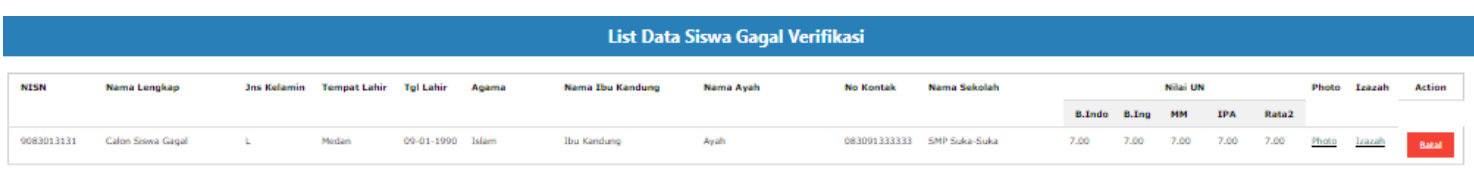

Gambar 18. Halaman data siswa lulus verifikasi. siswa lulus.

Untuk melihat dan membatalkan siswa yang lulus, maka admin harus mengakses halaman data

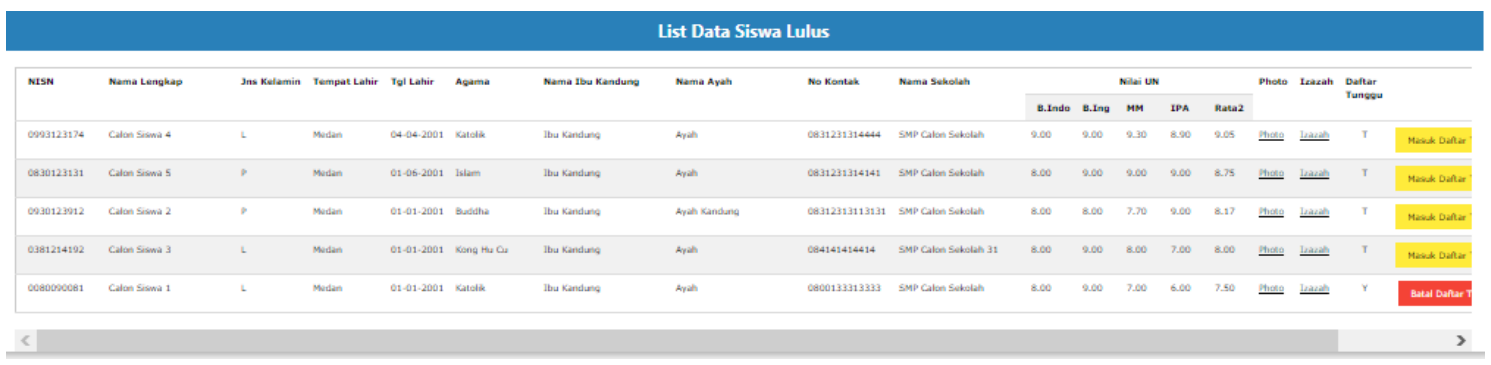

Gambar 19. Halaman data siswa lulus

Untuk melihat dan membatalkan data siswa yang tidak lulus, maka admin harus mengakses halaman data siswa tidak lulus.

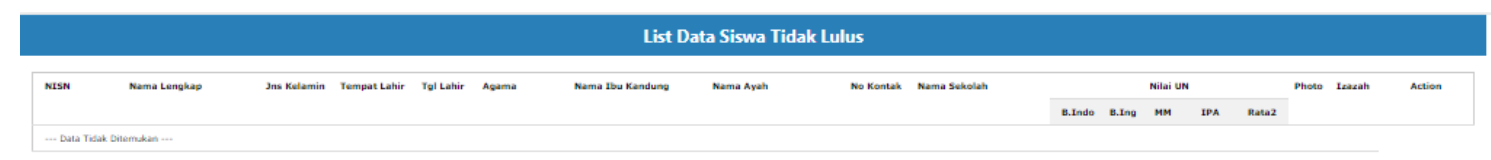

Gambar 20. Halaman data siswa tidak lulus

Untuk membuat pengumuman kelulusan, maka admin harus mengakses halaman pengumuman. 
Gambar 21. Halaman pengumuman kelulusan

\subsection{Pengujian dan Pembahasan}

Untuk memastikan sistem yang dibangun telah sesuai dengan kebutuhan, serta berjalan dengan baik, maka perlu dilakukan uji terhadap unit program dan integrasi sistem. Hasil pengujian terhadap unit program dan integrasi sistem dapat dilihat pada Tabel 1.

Tabel 1. Uji unit program dan integrasi sistem.

\begin{tabular}{|c|c|c|c|c|}
\hline No & Butir Uji & Hasil Yang Diharapkan & $\begin{array}{c}\text { Hasil Pengujian } \\
\end{array}$ & Kesimpulan \\
\hline 1 & $\begin{array}{l}\text { Membuka tampilan } \\
\text { masing-masing } \\
\text { halaman }\end{array}$ & $\begin{array}{l}\text { Menampilkan halaman sesuai } \\
\text { tujuan pengguna }\end{array}$ & $\begin{array}{l}\text { Sistem menampilkan halaman sesuai } \\
\text { tujuan } \\
\text { pengguna }\end{array}$ & Sesuai \\
\hline 2 & Form Log-in & Sistem mengelola log-in & $\begin{array}{l}\text { Sistem berhasil mengelola } \\
\text { Log-in }\end{array}$ & Sesuai \\
\hline 3 & Mendaftar Account & $\begin{array}{l}\text { Sistem menyimpan account sesuai } \\
\text { input dari pendaftar }\end{array}$ & $\begin{array}{l}\text { Sistem berhasil menyimpan account sesuai } \\
\text { input dari pendaftar }\end{array}$ & Sesuai \\
\hline 4 & Input Biodata & $\begin{array}{l}\text { Sistem menyimpan data sesuai } \\
\text { dengan input pengguna }\end{array}$ & $\begin{array}{l}\text { Sistem berhasil menyimpan data sesuai } \\
\text { dengan input pengguna }\end{array}$ & Sesuai \\
\hline 5 & $\begin{array}{l}\text { Upload Biodata } \\
\text { Pendukung }\end{array}$ & $\begin{array}{l}\text { Sistem menyimpan data yang di- } \\
\text { upload oleh pengguna }\end{array}$ & $\begin{array}{l}\text { Sistem berhasil menyimpan data yang di- } \\
\text { upload oleh pengguna }\end{array}$ & Sesuai \\
\hline 6 & Melihat Pengumuman & $\begin{array}{l}\text { Sistem menampilkan pengumuman } \\
\text { kelulusan }\end{array}$ & $\begin{array}{l}\text { Sistem berhasil menampilkan } \\
\text { pengumuman kelulusan }\end{array}$ & Sesuai \\
\hline 7 & Mendaftar Ulang & $\begin{array}{l}\text { Sistem menyimpan data peserta } \\
\text { yang mendaftar ulang }\end{array}$ & $\begin{array}{l}\text { Sistem berhasil menyimpan data peserta } \\
\text { yang mendaftar ulang }\end{array}$ & Sesuai \\
\hline 8 & Input atau Edit Artikel & $\begin{array}{l}\text { Sistem menyimpan data artikel } \\
\text { yang di-input dan diedit }\end{array}$ & $\begin{array}{l}\text { Sistem berhasil menyimpan data artikel } \\
\text { yang di-input dan diedit }\end{array}$ & Sesuai \\
\hline 9 & $\begin{array}{l}\text { Verifikasi Data Calon } \\
\text { Siswa }\end{array}$ & $\begin{array}{l}\text { Sistem menyimpan hasil verifikasi } \\
\text { data calon siswa }\end{array}$ & $\begin{array}{l}\text { Sistem berhasil menyimpan hasil verifikasi } \\
\text { data calon siswa }\end{array}$ & Sesuai \\
\hline 10 & $\begin{array}{l}\text { Ubah atau Hapus Data } \\
\text { Pengguna }\end{array}$ & $\begin{array}{l}\text { Sistem menghapus atau mengubah } \\
\text { data pengguna }\end{array}$ & $\begin{array}{l}\text { Sistem berhasil menghapus atau mengubah } \\
\text { data pengguna }\end{array}$ & Sesuai \\
\hline 11 & $\begin{array}{l}\text { Membuat Pengumuman } \\
\text { kelulusan }\end{array}$ & $\begin{array}{l}\text { nSistem menyimpan data } \\
\text { pengumuman kelulusan }\end{array}$ & $\begin{array}{l}\text { Sistem berhasil menyimpan data } \\
\text { pengumuman kelulusan }\end{array}$ & Sesuai \\
\hline 12 & $\begin{array}{l}\text { Menentukan Kelulusan } \\
\text { Siswa }\end{array}$ & $\begin{array}{l}\text { Sistem menyimpan data kelulusan } \\
\text { siswa }\end{array}$ & $\begin{array}{l}\text { Sistem berhasil menyimpan data kelulusan } \\
\text { siswa }\end{array}$ & Sesuai \\
\hline 13 & $\begin{array}{l}\text { Pengujian Integrasi } \\
\text { Sistem }\end{array}$ & $\begin{array}{l}\text { Sistem berjalan secara keseluruhan } \\
\text { tanpa ada error }\end{array}$ & $\begin{array}{l}\text { Sistem berhasil di jalankan secara } \\
\text { keseluruhan tanpa ada error }\end{array}$ & Sesuai \\
\hline
\end{tabular}

Sistem yang telah lulus uji unit program dan integrasi, di-publish ke server produksi untuk menjalankan operasi penerimaan siswa baru. Maintenance akan dilakukan apabila sistem mengalami kendala atau ada penambahan fitur.

Proses penerimaan siswa baru dengan menggunakan sistem informasi yang dibangun dilakukan pada tahun 2019, sedangkan pada tahun 2018 masih manual. Untuk memastikan data pendaftar valid maka data divalidasi dengan menggunakan NISN siswa. Jumlah data pendaftar pada tahun 2018 dan 2019 dapat dilihat pada Tabel 2.

Tabel 2. Data pendaftar pada tahun 2018 dan 2019.

\begin{tabular}{ccccccc}
\hline & \multicolumn{9}{c}{$\mathbf{2 0 1 8}$} & \multicolumn{2}{c}{$\mathbf{2 0 1 9}$} \\
\cline { 2 - 7 } & $\mathrm{P}$ & $\mathrm{L}$ & Total & $\mathrm{P}$ & $\mathrm{L}$ & Total \\
\hline Jumlah & 94 & 77 & 171 & 131 & 93 & 224 \\
\hline Validator & \multicolumn{3}{c}{ NISN } & \multicolumn{3}{c}{ NISN } \\
\hline
\end{tabular}

Berdasarkan data yang diperoleh, jumlah pendaftar pada tahun 2019 adalah 224 orang, sedangkan pada tahun pelajaran 2018 adalah 171 orang. Dengan menggunakan sistem informasi, terjadi peningkatan jumlah pendaftar sebanyak 53 orang atau sekitar 30\%, jika dibandingkan dengan sistem manual. 


\section{Kesimpulan}

Berdasarkan penelitian, maka ditarik kesimpulan bahwa pengembangan sistem informasi penerimaan siswa baru telah dibangun sesuai dengan kebutuhan sekolah dan sistemnya sudah berjalan dengan baik. Penggunaan sistem informasi penerimaan siswa baru meningkatkan jumlah pendaftar sebesar 30 persen, jika dibandingkan dengan sistem manual.

\section{Daftar Pustaka}

[1] Davit wijaya, "Manajemen Sumber Daya Manusia Pendidikan Berbasis Kompetensi Guru dalam Rangka Membangun Keunggulan Bersaing Sekolah," Pendidik. penabur, vol. 8, no. 12, pp. 68-89, 2009.

[2] Nur Komariah, "Konsep Manajemen Keuangan Pendidikan,” Al-Afkar, vol. VI, no. 1, pp. 67-94, 2018.

[3] Y. Latifah and H. Amalia, "Rancang Bangun Sistem Informasi Penerimaan Siswa Baru Dengan Model RAD," Perspektif, vol. XVI, no. 2, pp. 136-141, 2018.

[4] Y. Kusnadi and Mutoharoh, "PENGARUH KETERIMAAN APLIKASI PENDAFTARAN ONLINE TERHADAP JUMLAH PENDAFTAR DI SEKOLAH DASAR NEGERI JAKARTA,” Paradigma, vol. XVIII, no. 2, pp. 89-101, 2016.

[5] M. P. Susana Eviani, Syafrika Deni Rizki, "Sistem Informasi Penerimaan Siswa Baru Berbasis Web Pada Smpn 34 Kabupaten Tebo," Univ. Putra Indones. YPTK Padang, no. 1, pp. 1-7, 2016.

[6] Muhammad Iqbal Dzulhaq, Sutarman, and Sefti Wulandari, "Sistem Pendukung Keputusan Penerimaan Karyawan Dengan Metode Simple Additive Weighting (SAW)," Sisfotek Glob., vol. 7, no. 2, pp. 50-55, 2017.

[7] Rahman Setia Dedi and Bahar, "Model Sistem Informasi Penerimaan Siswa Baru Pada Madrasah Aliyah Negeri Berbasis Web," Jutisi, vol. 5, no. 3, pp. 1229-1238, 2016.

[8] R. Rizaldi, "Penerapan Waterfall Dalam Membangun Sistem Informasi Pengolahan data Pelaksanaan Konstruksi Pembangunan Jalan,” Jurteksi, vol. 4, no. 1, pp. 71-78, 2017.

[9] A. Lukito and A. Sadikin, "ANALISIS DAN PERANCANGAN APLIKASI PENJUALAN PADA,” J. Ilm. Media Process., vol. 10, no. 2, pp. 476-483, 2015.

[10] R. Fauzan, D. Siahaan, S. Rochimah, and E. Triandini, "Use Case Diagram Similarity Measurement: A New Approach," in 2019 12th International Conference on Information Communication Technology and System (ICTS), 2019, pp. 3-7.

[11] A. Firman, H. F. Wowor, X. Najoan, J. Teknik, E. Fakultas, and T. Unsrat, "Sistem Informasi Perpustakaan Online Berbasis Web," E-Journal Tek. Elektro Dan Komput., vol. 5, no. 2, pp. 29-36, 2016.

[12] G. W. Sasmito, "Penerapan Metode Waterfall Pada Desain Sistem Informasi Geografis Industri Kabupaten Tegal," vol. 2, no. 1, pp. 6-12, 2017. 